\title{
Próba zastosowania metody elementów dyskretnych w mechanice ciala stałego
}

\section{Tomasz Nowicki}

\author{
Katedra Mechaniki Budowli, Wydziat Budownictwa i Architektury, Politechnika Lubelska, \\ e-mail:t.nowicki@pollub.pl
}

Streszczenie: Praca poświęcona jest metodzie elementów dyskretnych. W chwili obecnej jest to metoda numeryczna służąca do modelowanie materiałów, głównie skał. W pracy zawarto opis najprostszej wersji metody. Przedstawiono również przeprowadzoną symulację komputerową z zastosowaniem pakietu obliczeniowego ESys-Particle. Artykuł należy traktować jako wprowadzenie do prac nad zastosowaniami tej metody w inżynierii budowlanej.

Słowa kluczowe: metoda elementów dyskretnych (odosobnionych), ESys-Particle, skala mezo.

\section{Wprowadzenie}

Metoda elementów dyskretnych jest obecnie jednym z podstawowych narzędzi numerycznych w mechanice skał [1-4]. W metodzie tej materiał reprezentuje się jako zbiór ciasno upakowanych kulistych cząstek wypełniających zadaną przestrzeń (Rys. 1). Cząstek tych jednak nie należy utożsamiać bezpośrednio z drobinami materiału. Cząstki te są bowiem etapem pośrednim pomiędzy mikroskopowymi cechami materiału a jego właściwościami makroskopowymi. Skalę modelu metody określa się jako skalę pośrednią, czyli mezo-skalę. Cząstki te kontaktują się ze sobą poprzez zaprojektowane lub wytworzone w trakcie symulacji interakcje. Odpowiedź materiału zależy przede wszystkim od właściwości tych interakcji. Właściwości takie jak np.: moduł Younga, odkształcenie czy pęknięcie nie są narzucone tylko pojawiają się jako efekt symulacji komputerowej. W związku z tym nie ma prostej relacji pomiędzy właściwościami makroskopowymi a parametrami interakcji. Cechą podstawową metody elementów dyskretnych jest rezygnacja z założenia o kontinuum materii. Założenie to pozwala opisać materiał za pomocą równań różniczkowych i całkowych, jednak stanowi problem w przypadku wystąpienia zjawisk fizycznych, które wykraczają poza to założenia np.: pękanie i zniszczenie. Posługiwanie się metodą elementów dyskretnych polega na odpowiednim zaprojektowaniu populacji dyskretnej. Populacja taka powinna $\mathrm{w}$ drodze symulacji komputerowej rozwijać zjawiska makroskopowe w sposób naturalny, tzn. niezaprogramowane a priori. Jest to zatem odmienne podejście niż w przypadku metody elementów skończonych, która stanowi obecnie standard w numerycznych symulacjach w dziedzinie mechaniki ciała stałego i konstrukcji budowlanych.

Niniejszy artykuł stanowi raport z pierwszej fazy studiów autora nad metodą elementów dyskretnych. Obejmuje on bogato ilustrowany dokładny opis najprostszej wersji metody oraz przedstawia symulację komputerową wykonaną przez autora. Artykuł ten rozpoczyna cykl prac poświęconych możliwości zastosowania metody elementów dyskretnych w mechanice materiałów i konstrukcji budowlanych. 


\section{Metoda elementów dyskretnych w mechanice ciala stałego}

\subsection{Podstawowa koncepcja metody elementów dyskretnych}

Metoda elementów dyskretnych (Discrete Element Method, DEM) stosowana w mechanice ciała stałego polega na zastosowaniu populacji dyskretnej w celu reprezentacji analizowanego materiału. Rysunek 1. przedstawia kostkę sześcienną o wymiarach $5 \times 5 \times 5 \mathrm{~cm}$ wykonaną z hipotetycznego materiału reprezentowaną za pomocą skończonego zbioru kul. Liczba kul w omawianym przykładzie wynosi 3334 sztuki. Kule stykają się ze sobą wewnątrz kostki oraz ze ścianami prostopadłościanu o ile takie istnieją. Liczba połączeń pomiędzy kulami wynosi 10 350. W miejscach styku kul występuje połączenie. Średnice kul znajdują się w przedziale od 2 do $10 \mathrm{~mm}$. Przestrzenny rozkład kul jest losowy. Charakterystyczną cechą takiego modelu materiału jest porowatość, którą liczymy jako stosunek objętości pustej przestrzeni do objętości całej próbki. W tym przypadku wynosi ona 0,35 .

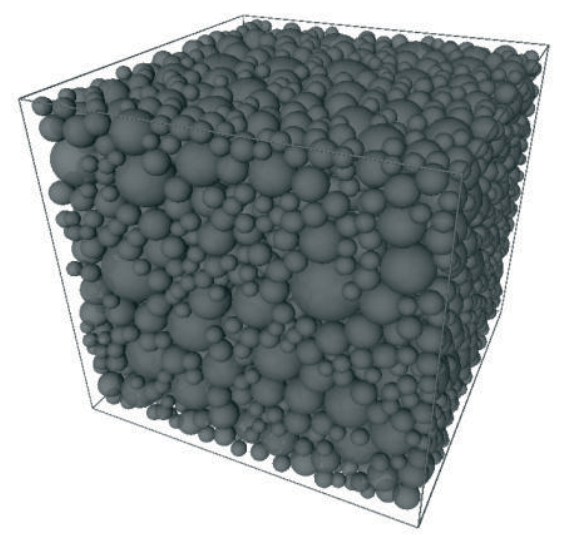

Rys. 1 . Model metody elementów dyskretnych, tutaj sześcian o wymiarach $5 \times 5 \times 5 \mathrm{~cm}$ wykonany $\mathrm{z}$ hipotetycznego materiału przedstawiony jako populacja dyskretna

Wybór kuli jako cząstki elementarnej metody podyktowane jest prostotą opisu geometrycznego i co za tym idzie implementacji komputerowej. Rozpatrzmy dwie dowolne stykające się cząstki kuliste (Rys. 2) o numerach i oraz j. Zarówno obie bryły jak i relacje między nimi są trójwymiarowe (Rys. 2a). Jednak przypadek taki redukuje się do zagadnienia jednowymiarowego (Rys. 2b), gdzie kierunkiem opisu jest prosta $k-k$ łącząca środki kul, tj. punkty $S_{i}$ oraz $S_{j}$. W związku z tym łatwo jest określić wzajemne położenie cząstek, znaleźć punkty połączenia lub kontaktu oraz określić stan połączenia lub kontaktu. Co w szczególności oznacza określenie wzajemnego oddziaływania cząstek na siebie. Przyjmujemy dalej, że oddziaływanie pomiędzy cząstkami może zachodzić tylko w kierunku $k-$ $k$. Nie uwzględniamy zatem tarcia między kulami.

a)

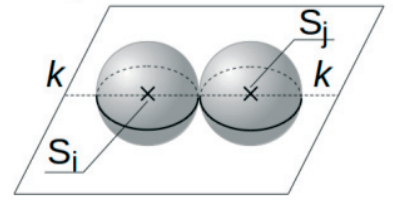

b)

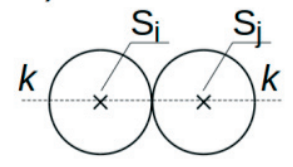

Rys. 2. Redukcja zagadnienia relacji wzajemnej dwóch cząstek trójwymiarowych. 
Dowolna cząstka kulista (Rys. 3) oznaczona numerem i jest bryłą sztywną. Możemy jej przypisać atrybuty skalarne: masę i promień (Rys. 3a). W celu określenia jej położenia w przestrzeni wystarczy wskazać położenie jej środka S, bowiem punkty na sferze są nierozróżnialne. Kula jako bryła sztywna w przestrzeni trójwymiarowej posiada 6 stopni swobody: 3 translacje oraz 3 rotacje. Jednak w podstawowej wersji metody elementów dyskretnych rezygnuje się z obrotowych stopni swobody zachowując jedynie translacje (Rys. 3b). W związku z tym jedynym istotnym oddziaływaniem na kulę jest siła F. Pod wpływem działania tej siły kula zmienia swoje położenie. Zatem opis cząstki uzupełniają atrybuty wektorowe: położenie $X$, prędkość $V$, przyśpieszenie $A$ oraz siła $F$. Wielkości te są związane równaniami mechaniki klasycznej. Uwzględniając wszystkie uproszczenia cząstkę kulistą metody elementów dyskretnych można traktować jako punkt materialny ze sferą otaczającą, która określa wzajemne oddziaływania cząstek na siebie.

a)

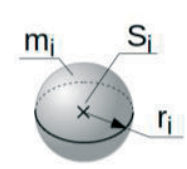

b)

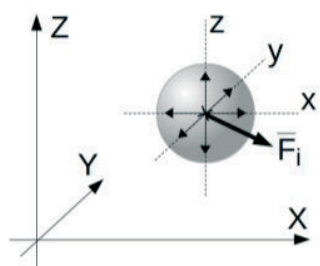

c)

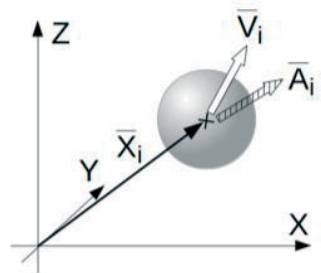

Rys. 3. Cząstka populacji dyskretnej jako punkt materialny.

Model ciała stałego realizowany jest poprzez wprowadzenie połączeń pomiędzy cząsteczkami „,b” (Rys. 4a). Połączenia te są rodzajem interakcji typu pierwszego i reprezentują one spójność materiału. W fazie inicjalizacji modelu wyszukiwane są wszystkie pary cząstek stykających się, tzn. takich których sfery otaczające oddalają się od siebie na odległość nie większą niż $\mathrm{d}_{0}$ lub penetrują się nie głębiej niż $d_{0}$. Jeżeli $\mathrm{w}$ modelu $\mathrm{w}$ tej fazie występują pary cząstek penetrujące się głębiej niż $d_{0}$ model uznaje się za wadliwy. W fazie początkowej odległość pomiędzy środkami tych cząstek wynosi $1_{0}$. Ruch cząsteczek powoduje, że zmienia się ich wzajemne położenie względem siebie. Parametrem połączenia jest zatem dystans d, który należy zawsze odnieść do parametru początkowego $d_{0}$. Jeżeli cząsteczki oddalają się od siebie (Rys. 4b) wówczas $d=d_{t}=l_{t}-l_{0}$, gdy zbliżają się do siebie (Rys. $4 \mathrm{c}$ ) to $d=d_{c}=l_{0}-l_{c}$. Zmiana dystansu wywołuje pojawienie się sił działających na cząsteczki. Siły działają na obie cząsteczki tak, aby przywrócić ich początkowe położenie. Kierunek tych sił pokrywa się z prostą łączącą środki kul, siły mają tą samą wartość i przeciwne zwroty. W przypadku oddalania się od siebie cząstek siły oznaczone $F_{t}$ zwrócone są do siebie, zaś w przypadku zbliżania się cząstek oznaczone $F_{c}$ i zwrócone są na zewnątrz układu. Wartość siły zależy od dystansu połączenia i wielkości cząstek.
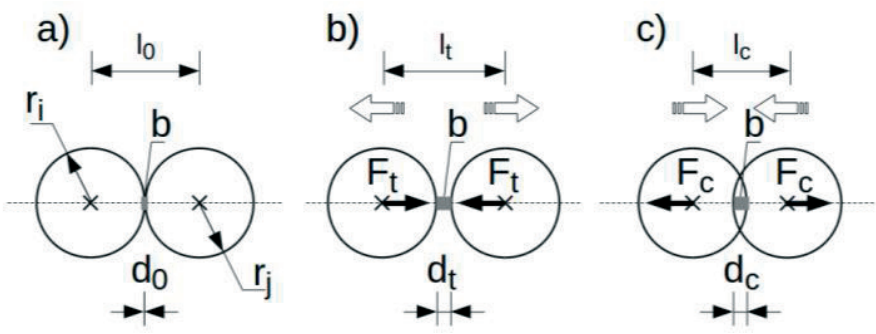

Rys. 4. Pierwszy typ interakcji między cząstkami - połączenie. 
Połączenia, które reprezentują spójność materiału, mogą ulec eliminacji, co oznacza zniszczenie materiału. W fazie początkowej połączenie znajduje się w stanie „zerowym” (Rys. 4a) w którym na cząstki nie oddziaływają żadne siły. W przypadku zwiększania się odległości między cząstkami, tj. rozciągania materiału, zwiększa się dystans połączenia i pojawią się siły działające na cząstki (Rys. 5b). Tę fazę można określić jako sprężystą. Jeżeli odległość ta ciągle się zwiększa, dystans połączenia osiąga maksymalną wartość i następuje jego zerwanie (Rys. 5c). Po zerwaniu połączenia na cząstki nie działają żadne siły. Zerwane połączenie nie jest regenerowane w trakcie symulacji. Analogiczne połączenie może zostać wyeliminowane w przypadku zmniejszaniu się odległości pomiędzy cząstkami (Rys. 6). Pierwszy przypadek odpowiada zniszczeniu poprzez rozciąganie, drugi poprzez ściskanie.

a)

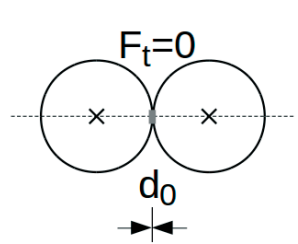

b)

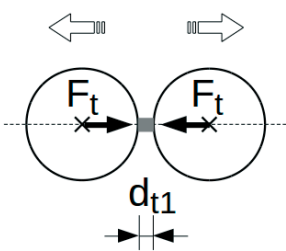

c)

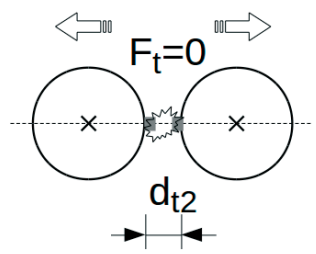

Rys. 5. Kolejne fazy pracy połączenia w przypadku rozciągania: a) położenie początkowe „zerowe”, b) faza sprężysta, c) zerwanie; $d_{0}<d_{t 1}<d_{t 2}$

a)

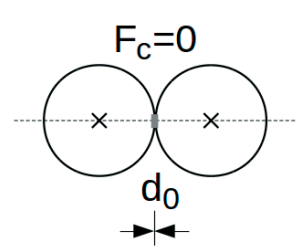

b)

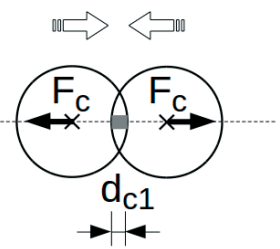

c)

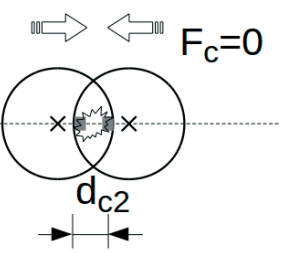

Rys. 6. Kolejne fazy pracy połączenia w przypadku ściskania: a) położenie początkowe, b) faza sprężysta, c) zerwanie; $d_{0}<d_{c 1}<d_{c 2}$

Interakcja typu drugiego oznacza odpychanie się cząstek, które się stykają (Rys. 7). Interakcje typu drugiego dotyczą cząstek, które nie realizują interakcji typu pierwszego, tzn. nie są połączone. Jeżeli dwie cząstki są połączone, to interakcja typu drugiego nie jest realizowana. Jeżeli sfery cząstek nie stykają się (Rys. 7a, 7b), wówczas nie działają na nie żadne siły. Jeżeli sfery nakładają się wówczas realizowane jest odpychanie.

a)

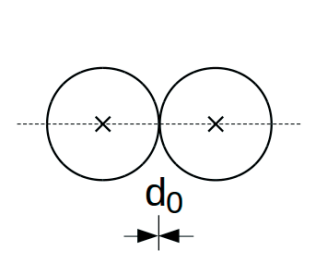

b)

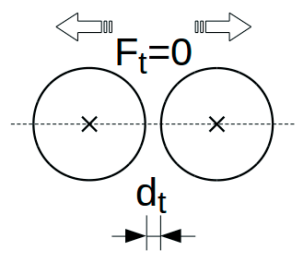

c)

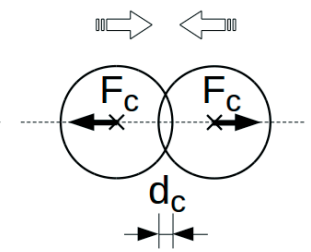

Rys. 7. Drugi typ interakcji pomiędzy cząsteczkami - odpychanie 
Związki konstytutywne, czyli zależności pomiędzy dystansem połączenia a siłami działającymi na cząstki, zobrazowane są na Rys. 8. Część a) dotyczy połączenia. Jest to połączenie sprężyste, w którym siła zależy liniowo od dystansu pomiędzy cząstkami. Połączenie funkcjonuje $\mathrm{w}$ zadanym zakresie dystansu od dopuszczalnej penetracji $d_{c \max }$ do maksymalnego oddalenia się cząstek od siebie $d_{t \max }$. W związku z tym istnieją maksymalne wartości siły zarówno przyciągającej jak i odpychającej cząstki. Przekroczenie dopuszczalnego zakresu dystansu powoduje zniszczenie połączenia. Zniszczone połączenie nie jest odnawiane. Związek konstytutywny przedstawiony na Rys. 8b określa w jaki sposób odpychają się cząstki, które nie są połączone. Część prawa wykresu oznacza brak siły odpychającej dla cząstek oddalonych od siebie. Część lewa wykresu opisuje siłę w przypadku nakładania się cząstek na siebie. Fragment wykresu od punktu „a” do „b”, zaznaczony również linią przerywaną na Rys. 8a, określa sposób zamiany interakcji typu pierwszego na typ drugi w przypadku zniszczenia połączenia wskutek ściskania.

a)

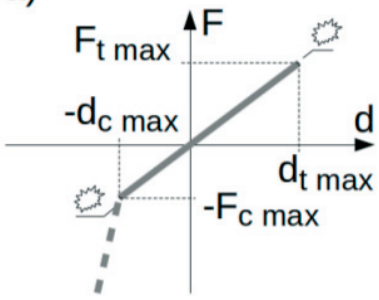

b)

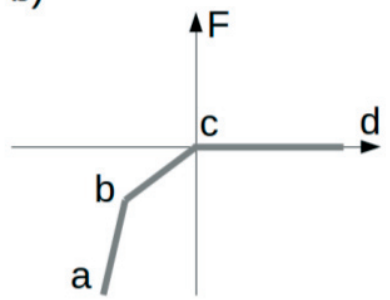

Rys. 8. Związek konstytutywny interakcji typu pierwszego a) i typu drugiego b) Lina przerywana na rysunku a) nie jest fragmentem wykresu opisującego związek.

Pozostaje jeszcze kwestia określenia wartości sił działających na cząstki w stanie interakcji. W opisywanym modelu zależności pomiędzy dystansem i siłą pozostają liniowe. Wartości tych sił zależą od sztywności materiału oraz od wielkości tych cząstek. Arbitralnym parametrem modelu jest wyłącznie sztywność interakcji. Natomiast „wielkość” połączenia zależy włącznie od wielkości cząstek i jest obliczana. W przypadku cząstek o tej samej średnicy (Rys. 9a) „wielkością” połączenia jest powierzchnia koła wielkiego jednej z nich. W przypadku cząstek o różnej średnicy powierzchnia koła wielkiego mniejszej cząstki (Rys. 9b). Powierzchnię tę nazywa się powierzchnią interakcji. Ostatecznie wartość siły interakcji wyliczamy ze wzoru:

$$
F=k \cdot A_{i j} \cdot d,
$$

gdzie: $F$ - wartość siły interakcji $F_{t}$ lub $F_{c}$ (patrz Rys.4), $k$ - sztywność interakcji, $A_{i j}-$ powierzchnia interakcji (patrz Rys. 9), $d$ - dystans interakcji $d_{t}$ lub $d_{c}$ (patrz Rys.4). W przypadku interakcji typu drugiego stosowane są albo jedna albo dwie różne wartości sztywności. Jednostką sztywności interakcji jest $\mathrm{N} / \mathrm{m}^{3}$ lub $\mathrm{Pa} / \mathrm{m}$.
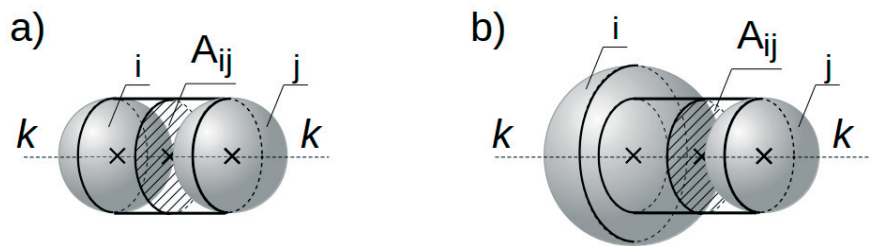

Rys. 9. Powierzchnia interakcji $A_{i j}$ (zakreskowane koło) w przypadku cząsteczek: a) o tej samej średnicy, b) o różnych średnicach 
Wszystkie interakcje występujące w populacji dyskretnej (Rys. 10) sprowadzane są do analizy par interakcji oraz superpozycji. Operacje te wykonuje się dla każdej z cząstek niezależnie. Po wyborze cząstki nr i (Rys. 10a) należy każdorazowo określić zbiór cząstek wchodzących $z$ nią w interakcje zarówno pierwszego jak i drugiego rodzaju. Zbiór ten na ilustracjach został oznaczony szarym kolorem. Następnie rozwiązuje się każdą interakcje pomiędzy każdym elementem zbioru a cząstką nr i. Rozwiązaniem każdej interakcji jest siła działająca na cząstkę i (Rys. 10b). Siły te sprowadza się do wypadkowej działającej na środek cząstki (Rys. 10c). Znając masę oraz siłę oblicza się aktualne przyśpieszenie cząstki. Uwzględniając jej aktualną prędkość znajdowane jest jej nowe położenie (Rys. 10c). Pierwszą fundamentalną zasadą metody elementów dyskretnych jest jednoczesna akcja całej populacji. Zasada ta realizowana jest w taki sposób, że najpierw wyliczane są siły wypadkowe i przyśpieszenia aktualne dla każdej cząstki, a następnie następuje zmian położenia każdej cząstki niezależnie. Drugą zasadą metody jest zasięg zmian możliwych do realizacji w pojedynczym kroku symulacji. Zmiana położenia cząstki nie może być duża, tzn. może wpływać wyłącznie na cząstki sąsiadujące (Rys. 10c)
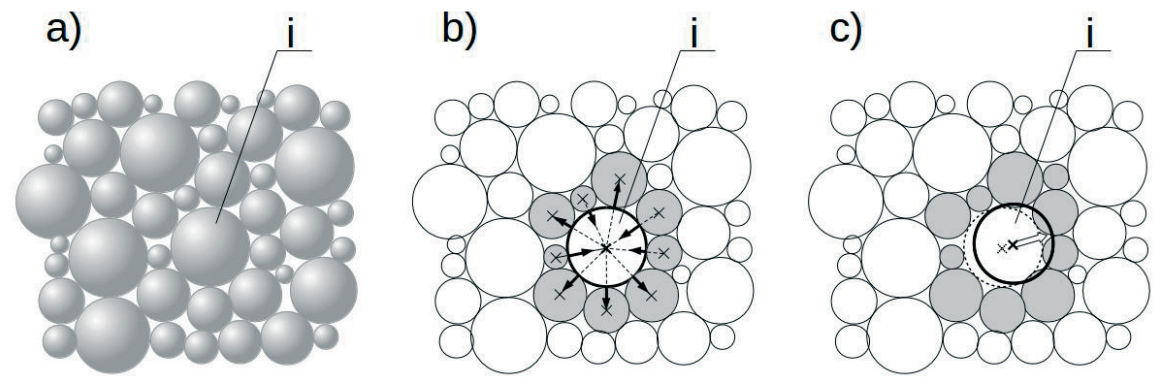

Rys. 10. Interakcje pojedynczej cząstki z populacją.

Dodatkowymi uczestnikami symulacji metodą elementów dyskretnych są ściany. Ściany stanowić mogą podpory lub służyć do przykładania obciążeń. Podobnie jak w przypadku interakcji pomiędzy ścianami i w tym przypadku zagadnienie można ograniczyć do problemu jednowymiarowego, w którym kierunkiem opisującym jest prostopadła poprowadzona od środka cząstki do powierzchni ściany (Rys. 11). W przypadku interakcji cząstki ze ścianą wprowadza się zazwyczaj drugi rodzaj interakcji. tzn. wyłącznie odpychanie w przypadku penetracji ściany przez kulkę. Zasady interakcji są analogiczne do interakcji pomiędzy dwoma cząstkami.

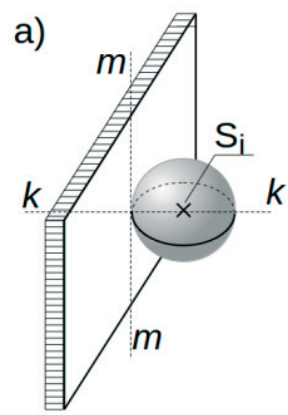

b)

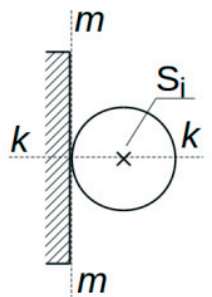

Rys. 11. Redukcja zagadnienia relacji wzajemnej cząstki i ściany: a) sytuacja trójwymiarowa, b) redukcja zagadnienia. 
a)

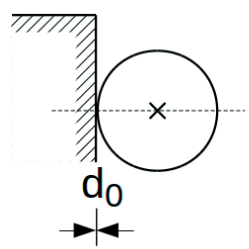

b)

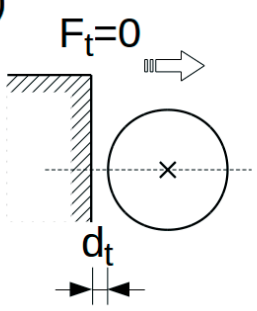

c)

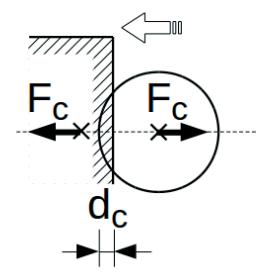

Rys. 12. Interakcja pomiędzy cząstką a ścianą.

\subsection{Implementacja metody elementów dyskretnych}

Obliczenia zaprezentowane w pracy zostały wykonane autorskim programem komputerowym napisanym w języku Python wykorzystującym biblioteki oraz silnika obliczeniowego ESys-Particle [5] i biblioteki graficznej VPython. ESys-Particle jest to naukowy framework obliczeniowy opracowany w Center of Geoscience Computing of The University of Queensland w Australii. Oprogramowanie to jest udostępniane bezpłatnie jako Open Source Code. Modułowy i w pełni obiektowy kod programu napisany jest w języku C++ $\mathrm{z}$ użyciem biblioteki MPI i jest natywnie przystosowany do pracy w środowisku wieloprocesorowym lub/i rozproszonym. Uruchomienie programu na pojedynczym procesorze jest realizowane również przez mechanizmy wielowątkowe. Obsługę programu wykonuje się poprzez dołączony interface języka Python, co umożliwia wygodną pracę za pomocą własnych skryptów.

ESys-Particle jest implementacją metody elementów dyskretnych wykraczającą dalece poza model opisany w niniejszej pracy. Oprogramowanie pozwala wykorzystywać cząstki posiadające nawet 7 stopni swobody, gdzie 6 stopni swobody dotyczy ruchu ciała (translacje i rotacje), zaś stopień 7 pozwala na dołączenie do symulacji pola skalarnego np. temperatury. Oprogramowanie oferuje wiele różnych teoretycznych modeli konstytutywnych połączeń. Nie dołączono jednak do pakietu konkretnych modeli materiałów. W pakiecie znajdują się podstawowe generatory struktur losowych.

\section{Przykładowa symulacja komputerowa metodą elementów dyskretnych}

\subsection{Założenia symulacji}

Prezentowana symulacja komputerowa jest wirtualnym testem kruszenia hipotetycznego materiału (Rys. 13). Z materiału tego jest wykona kostka o wymiarach $5 \times 5 \times 5 \mathrm{~cm}$. Składa się ona z 3334 kulistych cząstek DEM. Cząstki posiadają trzy stopnie swobody. W fazie początkowej występuje 10350 połączeń pomiędzy cząsteczkami. Zasady behawioralne populacji dyskretnej opisane są w poprzednich rozdziałach artykułu. Próbka dyskretna ujęta jest $\mathrm{z}$ góry i z dołu dwiema ścianami wizualizowanymi za pomocą płaskich krążków. Ściany zbliżają się do siebie ze stałą prędkością. Powoduje to przyłożenie sił do zewnętrznych warstw kostki (dolnej i górnej), a następnie rozdystrybuowanie tych sił wewnątrz materiału. W ten sposób uzyskiwane jest ściskanie całej próbki. W kolejnych krokach symulacji uzyskiwana jest odpowiedź populacji dyskretnej na tak zaprojektowane oddziaływanie. Odpowiedź ta formuje się w makroskopowe zachowanie materiału. 


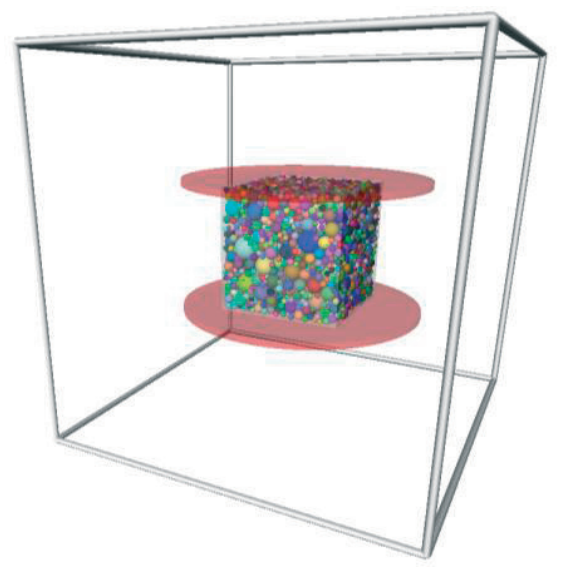

Rys. 13. Wirtualny test ściskania hipotetycznego materiału. Kolor cząstek jest wygenerowany losowo.

Parametry modelu zostały dobrane w taki sposób, symulacja mogła zostać przeprowadzona na komputerze średniej klasy w krótkim czasie, tzn. mniej niż 1 godzina. Gęstość materiału przyjęto równą $1000 \mathrm{~kg} / \mathrm{m}^{3}$. W symulacji komputerowej nie wprowadzono siły ciężkości. Sztywność interakcji zarówno pierwszego i drugiego rodzaju ustalono na $1000 \mathrm{~N} / \mathrm{m}^{3}$. Interakcja pierwszego rodzaju (połączenie) zostaje zniszczone, jeżeli jego dystans osiągnie wartość $1 \mathrm{~mm}$. Dotyczy to zarówno ściskania jak i rozciągania. Obie płyty poruszają się względem środka kostki ruchem jednostajne przyśpieszonym z przyśpieszeniem $0,001 \mathrm{~m} / \mathrm{s}^{2}$. W chwili rozpoczęcia symulacji płyty są nieruchome. Krok czasowy symulacji wynosi $0,001 \mathrm{~s}$. Zaprezentowana symulacja składa się ze 100 kroków, zatem obejmuje czas $0,1 \mathrm{~s}$. W ostatnim kroku symulacji prędkość płyt wynosi $0,0001 \mathrm{~m} / \mathrm{s}$ względem środka kostki, co oznacza prędkość $0,0002 \mathrm{~m} / \mathrm{s}$ względem siebie.

\subsection{Wyniki symulacji}

Kolejne ilustracje (Rys. 14 i 15) przedstawiają wizualizację wirtualnej próbki w kolejnych etapach symulacji. W kroku 10 nie zauważono znaczących zmian w wyglądzie obiektu. Na tym etapie płyty docierają do próbki. Cząstki bezpośrednio stykające się z płytą doznają niewielkich przemieszczeń pod wpływem działających na nie sił.
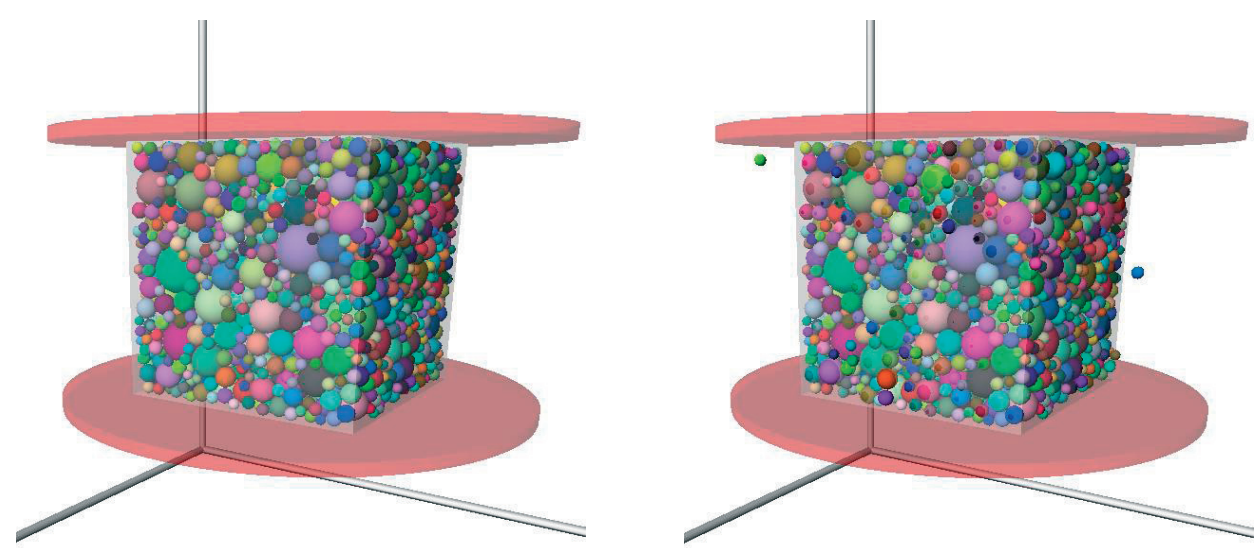

Rys. 14. Obraz próbki w (od lewej) 10 i 50 kroku symulacji 
W kroku 50 rozpoczyna się destrukcja połączeń. Pojawiają się odłamy i odpryski, które widoczne są na wizualizacji. W kroku 75 znaczna część połączeń została zniszczona. W próbce tworzą się tymczasowe kolumny poprzez spontaniczne ułożenie się na sobie warstw cząstek. W ostatnim kroku symulacji, tj. nr 100, próbka została całkowicie rozkruszona.
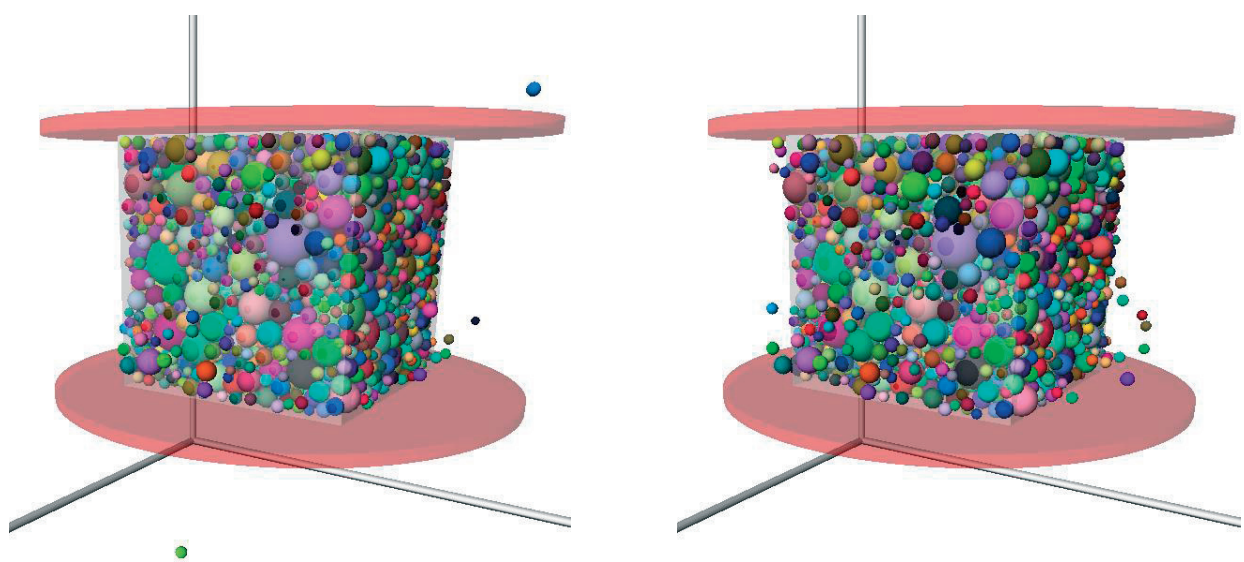

Rys. 15. Obraz próbki w (od lewej) 75 i 100 kroku symulacji

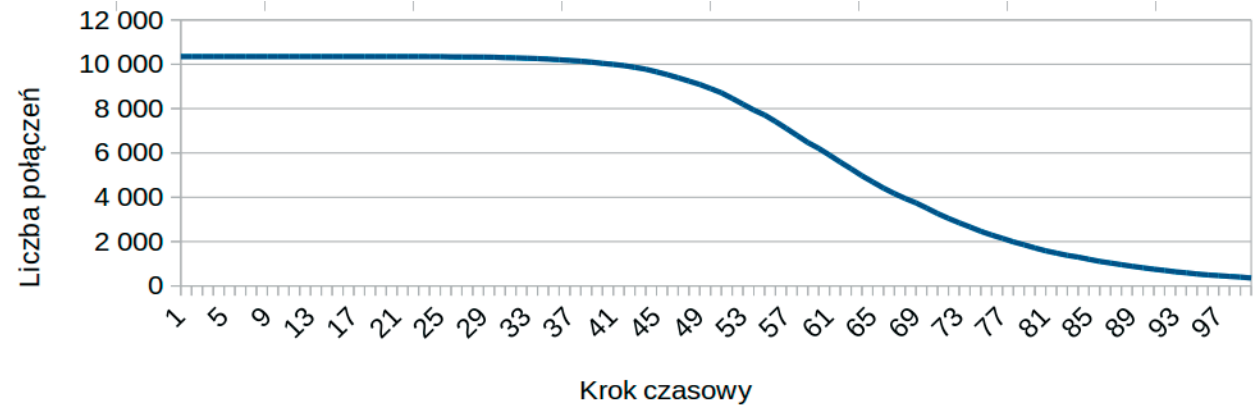

Rys. 16. Liczba aktywnych więzów pierwszego rodzaju (niezerwanych połączeń) w trakcie symulacji

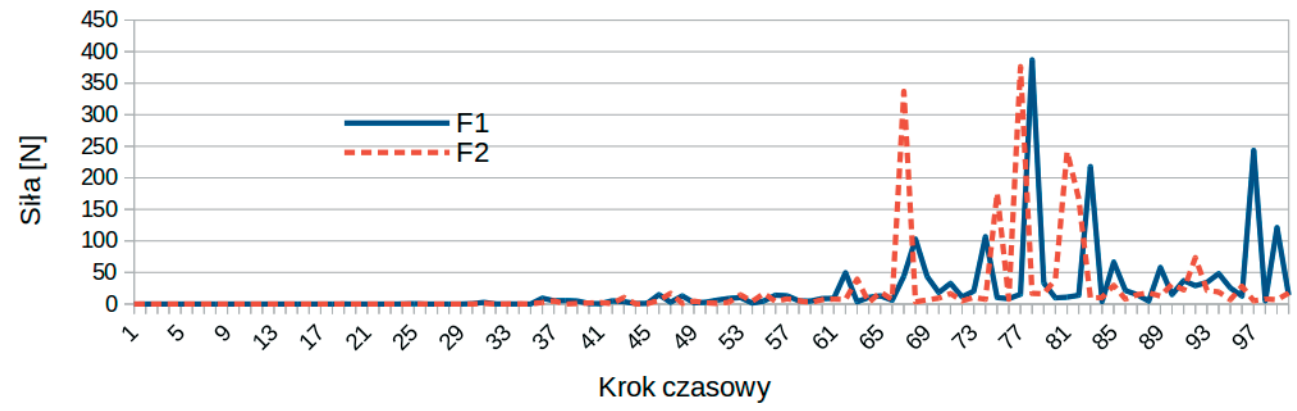

Rys. 17. Wartości wypadkowych sił działających na ściany F1 - górną, F2 - dolną 
Wykres na Rys. 16 przedstawia liczbę istniejących, tzn. nie zniszczonych, połączeń w próbce. Natomiast wykres na Rys. 17 pokazuje siły działające na płyty w trackie testu. W początkowej fazie siły są niewielkie co wynika z niedużych przemieszczeń płyt względem próbki (małe prędkości płyty). Po zbliżeniu się płyt do próbki oraz uszczelnieniu styku (wskutek przemieszczeń cząstek w kontakcie z płytą) widzimy nagłe wzrosty i spadki wartości siły. Związane jest to z niszczeniem kolejnych połączeń w próbce. Natomiast wartości sił należy traktować jako orientacyjne.

\title{
4. Podsumowanie i wnioski
}

W pracy przestawiono najprostszą wersję metody elementów dyskretnych. Następnie została przeprowadzona symulacja z jej użyciem. Symulacja polegała na przeprowadzeniu testu kruszenia poprzez ściskanie. Należy zwrócić uwagę, że pomimo prostoty przyjętego modelu rezultat jest zbliżony do rzeczywistego. Podkreślić też można fakt, że przeprowadzenie podobnej symulacji z użyciem metody elementów skończonych byłoby o wiele bardziej pracochłonne. Zaprezentowane wyniki badań mają charakter wstępny, a prace nad metodą elementów dyskretnych w zastosowaniach do mechaniki materiałów i konstrukcji budowlanych będą kontynuowane.

\section{Literatura}

1 Cundall P. A., Strack O.D.L. A discrete numerical model for granular assemblies. Geotechnique 29(1) (1979) 47-65.

2 Mora P., Place D. Simulation of the frictional stick-slip instability. Pure Appl. Geophys. 143(13) (1994) 61-87.

3 Abe S., Place D., Mora P., A parallel implementation of the lattice solid model for the simulation of rock mechanics and earthquake dynamics. Computational Earthquake Science Part II, pp. 2265-2277, Springer, Basel, Switzerland (2004).

4 Potyondy D.O., Cundall P.A. A bonded-particle model for rock. Int. J. Rock Mech. Min. Sci., 41(8) (2004) 1329-1364.

$5 \quad$ Weatherley D., Hancock W., Boros V. ESyS-Particle Tutorial and User's Guide Version 2.3.1; The University of Queensland, Institute for Geothermal Resource Management, 2014.

\section{An attempt to use Discrete Element Method in solid mechanics}

\author{
Tomasz Nowicki \\ Department of Structural Mechanics, Faculty of Civil Engineering and Architecture, \\ Lublin University of Technology,e-mail: t.nowicki@pollub.pl
}

Abstract: The paper is devoted to Discrete Element Method. Currently the method is mainly used for mechanics of rock. The paper contains the description of the simplest version of the method. Computer simulation using Esys-Particle computer code is presented. The paper is an introduction to the study on the method applications to building engineering.

Keywords: discrete element method, mezoscale, Esys-Particle. 